plots. At Tamarack, species richness was also greatest in the underburned areas, but herbicide-treated areas exceeded untreated areas. At this site, the area without a herbicide treatment demonstrated the lowest slope as well as the smallest number of species at each quadrat size. Species richness was nearly identical between the herbicide-treated and underburned forest at Pondosa, whereas species richness in the untreated site was significantly reduced. These results support the finding obtained using the plant diversity indices.

There was little apparent change in the species composition between the untreated and the herbicide-treated areas.

\section{Conclusions}

Results of this investigation demonstrate the importance of herbicide site preparation for successful reforestation following catastrophic fire. In the absence of shrub control, competition for water (and perhaps light) can lead to the suppression of both conifer seedlings and many of the indigenous native herbaceous species.

Despite the initial reduction in plant diversity and species richness in herbicide-treated areas, the native plant diversity was not statistically different from that of the unburned forest sites 8 years after the treatment. In contrast, untreated burned areas demonstrated a long-term reduction in plant diversity and species richness compared to the unburned site. Although the untreated area had a similar level of vegetative cover to the unburned or herbicide-treated site, the vegetation was dominated by only a few shrubby species, particularly Ceanothus spp. and Arctostaphylos patula.

J.M. DiTomaso is Non-Crop Extension Weed Ecologist, Department of Vegetable Crops, UC Davis; D.B. Marcum is Farm Advisor, Shasta-Lassen Counties; M.S. Rasmussen and E.A. Healy are summer interns, UC Davis; and G.B. Kyser is Research Support, Department of Vegetable Crops, UC Davis.

This research was supported by UCDANR North Region.

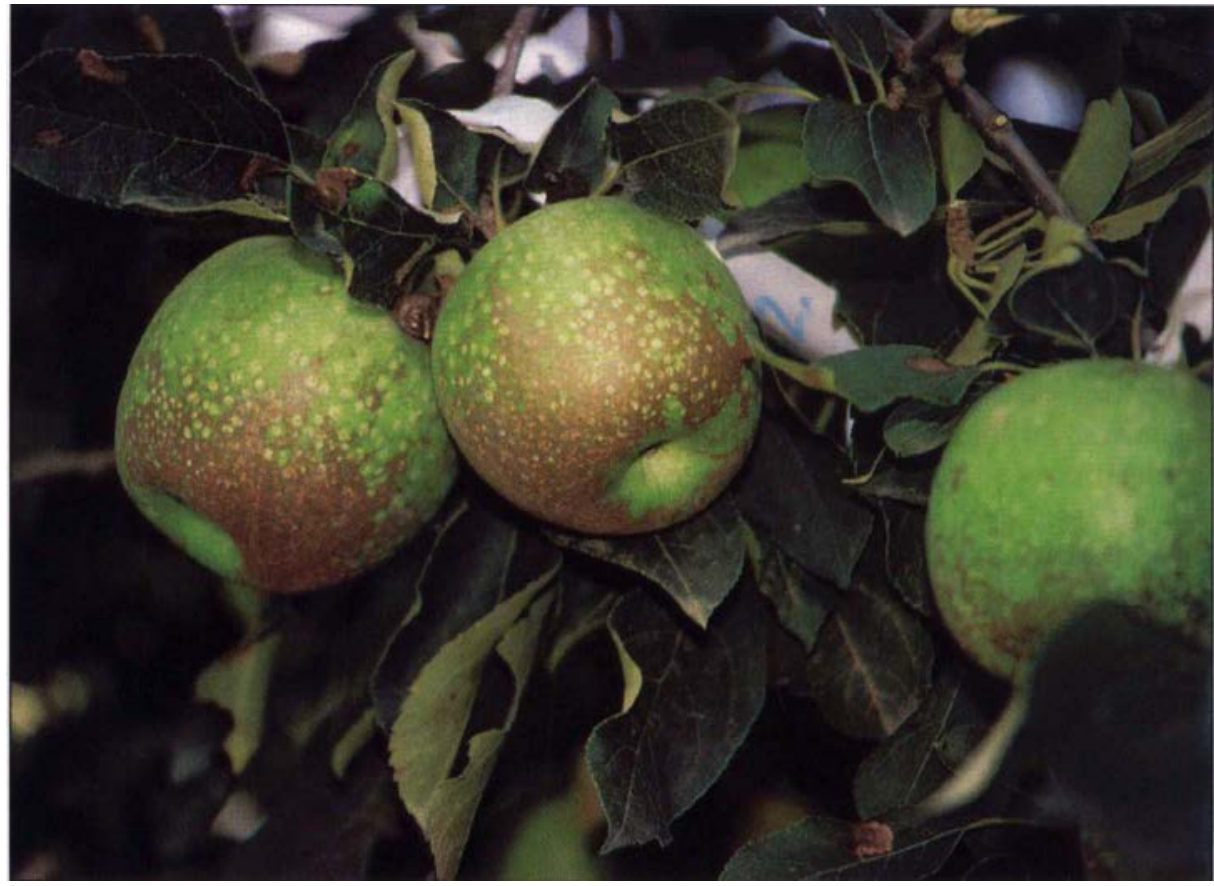

The severity of russetting on Granny Smith apples increased with increasing numbers of copper treatments used to control fire blight during bloom.

\title{
Apple russetting influenced by more than copper sprays
}

\author{
Beth L. Teviotdale $\square$ Mario Viveros $\square$ Joseph A. Grant
}

Apple trees are commonly treated with antibiotics during bloom and early shoot growth to control fireblight, but antibiotic resistance is a concern. To prevent antibiotic resistance, copper treatments may be beneficial, but would be feasible only if stages in bloom or fruit development could be identified that are not subject to fruit russetting. Most fruit russetting results from injury to epidermal cells early in fruit development. Studies in Kern and San Joaquin counties showed copper-induced russetting of apple fruit was unpredictable and sporadic regardless of application timing. Severity of damage varied from year to year.
Apple trees are susceptible to fire blight, a bacterial disease that kills flowers and young shoots. In very susceptible cultivars the disease can destroy large scaffolds or entire trees. The pathogen, Erwinia amylovora, overwinters in the tree and is spread in spring chiefly by rain and insects. Infections occur mainly through flowers, although succulent vegetative shoots are also attacked. Fire-blight epidemics are promoted by moderate temperatures and wet or humid weather during bloom. Fire blight is controlled with bactericide treatments during and shortly after bloom, removal of infected shoots or branches throughout the year and specific cultural practices such as avoiding irrigation during bloom and limiting nitrogen fertilization. 


\section{Antibiotic resistance}

The basis of fire-blight control in apple trees is treatment during bloom and early shoot growth periods. The only effective materials are the antibiotic streptomycin-sulfate and products that contain copper. Growers rely on streptomycin-sulfate because copper may result in unacceptable fruit russetting of several commercial apple cultivars. On the other hand, multiple applications of streptomycin-sulfate during any growing season can promote antibiotic resistance in the pathogen that erodes the effectiveness of subsequent antibiotic treatments. Therefore, reducing the number of streptomycin-sulfate applications in fire-blight management programs would help minimize the risk of resistance development.

The recent discovery of streptomycin-sulfate resistant $E$. amylovora strains in apple orchards in several counties in the San Joaquin Valley stimulated interest in finding alternatives to the antibiotic. Copper is an obvious possibility: it is registered for use on apples, is readily available and was used for fire-blight control before antibiotics were discovered. Although generally less effective than antibiotics for fire-blight control, it is an acceptable alternative.

Copper has been tested extensively in apple fire-blight control programs in many regions over several decades. The aggregate wisdom from these tests points to great variability in the severity of phytotoxic responses to copper treatment. Factors that affect phytotoxicity include the copper compound, its formulation and concentration, the cultivar and the stage of tree growth when treated. Climate and other unknown elements also probably affect russet incidence and severity. A treatment program that includes copper may be beneficial, but would be feasible only if stages in bloom or fruit development could be identified that are not subject to fruit russetting. Here we report our observations of russetting of 'Granny Smith' and 'Fuji' apple fruit on trees treated with copper at various times during and after bloom.

\section{Treatment timing}

'Granny Smith' apples. Experiments were conducted in a commercial orchard planted in 1981 in Kern County. Trees were free standing, central-leader trained, and spaced 16 feet by 18 feet. The orchard was irrigated with overhead sprinklers, beginning with a prebloom irrigation. No water was applied during bloom. After bloom, the orchard was irrigated every 4 days for 24 hours. All orchard practices were standard for the cultivar and region.

TABLE 1. Incidence of russetting of 'Granny Smith' apple fruit from trees treated with copper bactericide, Kern County

\begin{tabular}{|c|c|c|c|c|c|c|c|c|}
\hline \multirow{4}{*}{$\begin{array}{l}\text { Growth stage } \\
\text { when treated }\end{array}$} & \multicolumn{8}{|c|}{ Russetted fruit* } \\
\hline & \multicolumn{2}{|c|}{1990} & \multicolumn{3}{|c|}{1991} & \multicolumn{3}{|c|}{1992} \\
\hline & \multirow{2}{*}{$\begin{array}{l}\text { Kocide } 101 \\
\text { (lb/100 gal) } \\
\frac{0.25}{}\end{array}$} & \multirow{2}{*}{$\begin{array}{c}\text { Water } \\
\text { control }\end{array}$} & \multicolumn{2}{|c|}{$\begin{array}{l}\text { Kocide } 101 \\
\text { (lb/100 gal) }\end{array}$} & \multirow[t]{2}{*}{$\begin{array}{l}\text { Water } \\
\text { control }\end{array}$} & \multicolumn{2}{|c|}{$\begin{array}{l}\text { Kocide } 101 \\
\text { (lb/100 gal) }\end{array}$} & \multirow[t]{2}{*}{$\begin{array}{l}\text { Water } \\
\text { control }\end{array}$} \\
\hline & & & 1.0 & 0.25 & & $\overline{1.0}$ & 0.25 & \\
\hline \multicolumn{9}{|l|}{ King bloom } \\
\hline Pink bud & 0.0 ał & $0.7 \mathrm{a}$ & $11.0 \mathrm{a}$ & $3.5 \mathrm{~b}$ & $0.0 \mathrm{c}$ & $67.0 \mathrm{a}$ & $13.7 b$ & $0.0 \mathrm{c}$ \\
\hline Full bloom & $0.5 \mathrm{a}$ & $0.0 \mathrm{a}$ & $18.9 \mathrm{a}$ & $5.5 \mathrm{~b}$ & $3.5 \mathrm{~b}$ & $71.7 \mathrm{a}$ & $53.5 \mathrm{~b}$ & $0.0 \mathrm{c}$ \\
\hline Petal fall & $2.0 \mathrm{a}$ & $0.0 \mathrm{a}$ & $4.3 \mathrm{a}$ & $5.6 \mathrm{a}$ & $1.4 \mathrm{a}$ & $82.5 \mathrm{a}$ & $63.0 \mathrm{~b}$ & $0.5 \mathrm{c}$ \\
\hline \multicolumn{9}{|l|}{ King fruitt } \\
\hline 7.1 & $4.3 \mathrm{a}$ & $0.0 \mathrm{a}$ & $9.5 \mathrm{a}$ & $1.4 \mathrm{a}$ & $2.2 \mathrm{a}$ & $2.2 \mathrm{a}$ & $4.0 \mathrm{a}$ & $0.2 \mathrm{a}$ \\
\hline 13.5 & $3.0 \mathrm{a}$ & $0.0 \mathrm{a}$ & $8.4 \mathrm{a}$ & $2.9 \mathrm{a}$ & $1.1 \mathrm{a}$ & $0.7 \mathrm{a}$ & $4.2 \mathrm{a}$ & $0.2 \mathrm{a}$ \\
\hline 18.9 & $0.2 \mathrm{a}$ & $0.0 \mathrm{a}$ & $20.8 \mathrm{a}$ & $9.2 \mathrm{~b}$ & $1.6 \mathrm{~b}$ & $1.5 \mathrm{a}$ & $0.5 \mathrm{a}$ & $1.5 \mathrm{a}$ \\
\hline 25.6 & - & - & $12.6 \mathrm{a}$ & $4.9 \mathrm{~b}$ & $0.0 \mathrm{c}$ & $3.7 \mathrm{a}$ & $3.5 \mathrm{a}$ & $0.0 \mathrm{a}$ \\
\hline 33.4 & - & - & $10.6 \mathrm{a}$ & $2.9 \mathrm{~b}$ & $0.0 \mathrm{~b}$ & $0.5 \mathrm{a}$ & $1.7 \mathrm{a}$ & $1.7 \mathrm{a}$ \\
\hline Every week & $29.3 \mathrm{a}$ & $0.0 \mathrm{~b}$ & $39.1 \mathrm{a}$ & $20.9 \mathrm{~b}$ & $1.1 \mathrm{c}$ & $97.0 \mathrm{a}$ & $88.5 \mathrm{a}$ & $0.2 \mathrm{~b}$ \\
\hline
\end{tabular}

"One hundred mature fruit per replication selected arbitrarily on the day of evaluation and near commercial harvest each year.

$\dagger$ Fruit diameter $(\mathrm{mm})$ averaged over 3 years.

$\ddagger$ Means across rows, within each year, that share the same letter do not differ significantly according to

Duncan's multiple range test, $\mathrm{P}=0.05$.

We evaluated damage to mature fruit on trees treated with copper at various stages of flower and fruit development. In 1990, we applied $0.25 \mathrm{lb}$ Kocide 101 per 100 gallons of water to different trees once at weekly intervals and for another treatment once a week repeatedly for 6 weeks. In 1991 and 1992 , we applied 0.25 and $1.0 \mathrm{lb}$ Kocide 101 per 100 gallons of water at weekly intervals and once a week repeatedly for 8 weeks. Each year, controls included trees similarly treated with water and nontreated trees. Trees were sprayed until run-off using a John Bean hand-gun sprayer operated at 400 psi. Experiments were located on different trees each year. There were four single-tree replications of each treatment in a randomized complete block design.

Treatment timing was based on the development of the king blossom and fruit. The king blossom, which is the central and largest flower in the flower cluster, opens first and gives rise to the largest fruit. The first, second and third copper applications were made when $80 \%$ to $100 \%$ of the king blossoms were at pink bud, full bloom and petal fall, respectively. For each succeeding week, we determined the average size of the king fruit by measuring the largest diameter of 40 randomly collected king fruit each day of treatment. Fruit diameters when treated, averaged over the 3 years, were $7.1,13.5,18.9,25.6$ and $33.4 \mathrm{~mm}$ for treatment weeks 4 through 8 , respectively. The first treatment occurred on March 15, 1990, March 11, 1991 and March 12, 1992. Because there were fruit of various sizes and stages of development on the trees when treated, 25 (1990) or 50 (1991 and 1992) king fruit at the average fruit size, $+/-1 \mathrm{~mm}$, for each treatment date, were tagged on each tree immediately before treatment each week for later evaluation.

Fruit russetting was evaluated on Sept. 15, 1990, Sept. 5, 1991 and Aug. 24, 1992. The tagged fruit and 100 fruit selected arbitrarily on the day of evaluation were removed from each tree and rated visually according to a scale based on percentage of fruit surface russetted: $0=0 \%, 1=1 \%$ to $5 \%, 2$ 
$=6 \%$ to $15 \%, 3=16 \%$ to $50 \%, 4=51 \%$ to $75 \%$ and $5=76 \%$ to $100 \%$. Fruit in categories 3, 4 and 5 were described by the grower as culls.

Russetting was minimal in 1990 and 1991. Less than 5\% (1990) and $20 \%$ (1991) of fruit were scarred in random samples from trees treated once in any given week with Kocide 101, whereas nearly 30\% (1990) and 40\% (1991) of fruit from trees treated every week were russetted (table 1). However, no fruit were scored as culls. Watertreated and nontreated controls were healthy. Similar results were obtained from tagged fruit, and the russet rating for random and tagged fruit samples was less than 0.50 for all treatments (data not presented).

In 1992, russetting was severe in some treatments. Among random samples from single applications of 1.0 lb Kocide 101, more than $60 \%$ of fruit from trees treated during bloom were russetted, whereas russetting was negligible in postbloom treatments and the water controls (table 1). At all three bloom stages, scarring was significantly greater in the $1.0 \mathrm{lb}$ than in the $0.25 \mathrm{lb}$ Kocide 101 treatment, and

TABLE 2. Severity of russetting of 'Granny Smith' apple fruit from trees treated with copper

\begin{tabular}{|c|c|c|c|c|c|c|}
\hline \multirow{3}{*}{$\begin{array}{l}\text { Growth stage } \\
\text { when treated }\end{array}$} & \multicolumn{3}{|c|}{ Russet rating* } & \multicolumn{3}{|c|}{ Cull fruit $(\%)^{*}$} \\
\hline & \multicolumn{2}{|c|}{ Kocide 101 (lb/100 gal) } & \multirow{2}{*}{$\begin{array}{l}\text { Water } \\
\text { control }\end{array}$} & \multicolumn{2}{|c|}{ Kocide 101 (lb/100 gal) } & \multirow{2}{*}{$\begin{array}{l}\text { Water } \\
\text { control }\end{array}$} \\
\hline & 1.0 & 0.25 & & 1.0 & 0.25 & \\
\hline \multicolumn{7}{|l|}{ King bloom } \\
\hline Pink bud & 1.33 at & $0.30 \mathrm{~b}$ & $0.00 \mathrm{c}$ & $22.2 \mathrm{a}$ & $3.7 \mathrm{~b}$ & $0.0 \mathrm{c}$ \\
\hline Full bloom & $1.72 \mathrm{a}$ & $1.04 b$ & $0.00 c$ & $31.2 \mathrm{a}$ & $15.7 b$ & $0.0 \mathrm{c}$ \\
\hline Petal fall & $2.35 \mathrm{a}$ & $1.29 \mathrm{~b}$ & $0.01 \mathrm{c}$ & $55.0 \mathrm{a}$ & $22.0 \mathrm{~b}$ & $0.0 \mathrm{c}$ \\
\hline \multicolumn{7}{|l|}{ King fruitł } \\
\hline 7.1 & $0.03 a$ & $0.00 a$ & $0.01 \mathrm{a}$ & 0.0 & 0.0 & 0.0 \\
\hline 13.5 & $0.01 \mathrm{a}$ & $0.03 a$ & $0.01 \mathrm{a}$ & 0.0 & 0.0 & 0.0 \\
\hline 18.9 & $0.02 \mathrm{a}$ & $0.01 \mathrm{a}$ & $0.01 \mathrm{a}$ & 0.0 & 0.0 & 0.0 \\
\hline 25.6 & $0.06 a$ & $0.01 \mathrm{a}$ & $0.01 \mathrm{a}$ & 0.7 & 0.0 & 0.0 \\
\hline 33.4 & $0.01 \mathrm{a}$ & $0.02 \mathrm{a}$ & $0.02 \mathrm{a}$ & 0.0 & 0.0 & 0.0 \\
\hline Every week & $3.76 \mathrm{a}$ & $2.27 \mathrm{~b}$ & $0.01 c$ & $82.5 \mathrm{a}$ & $51.0 \mathrm{~b}$ & $0.0 \mathrm{c}$ \\
\hline
\end{tabular}

"One hundred mature fruit per replication were selected arbitrarily on the day of evaluation and near commercial harvest. Russet rating scale of 0 to 5 , with $0=$ no russetting and $5=75$ to $100 \%$ of fruit russetted. Cull fruit were those in russet rating categories 3,4 and 5.

†Means across rows, within russet rating or cull fruit categories, that share the same letter do not differ significantly according to Duncan's multiple range test, $P=0.05$.

†Fruit diameter $(\mathrm{mm})$ averaged over 3 years.

TABLE 3. Effects on russetting of 'Granny Smith' apple fruit from trees treated with copper bactericide at different stages of bloom followed by treatment with streptomycin sulfate, Kern County, 1992

\begin{tabular}{|c|c|c|c|c|c|c|}
\hline \multicolumn{4}{|c|}{ Treatment timing and material* } & \multirow[b]{2}{*}{$\begin{array}{c}\text { Russetted } t \\
\text { fruit }\end{array}$} & \multirow[b]{2}{*}{$\begin{array}{c}\text { Russet† } \\
\text { rating }\end{array}$} & \multirow[b]{2}{*}{$\begin{array}{l}\text { Culledt } \\
\text { fruit }\end{array}$} \\
\hline $\begin{array}{l}\text { Pink } \\
\text { bud }\end{array}$ & $\begin{array}{l}\text { Full } \\
\text { bloom }\end{array}$ & $\begin{array}{c}\text { Petal } \\
\text { fall }\end{array}$ & Later & & & \\
\hline $\begin{array}{l}K \\
K \\
K\end{array}$ & $\begin{array}{l}\mathrm{K} \\
\mathrm{K} \\
\mathrm{K}\end{array}$ & $\begin{array}{l}\mathrm{K} \\
\mathrm{K} \\
\mathrm{K}\end{array}$ & $\begin{array}{l}S \\
W\end{array}$ & $\begin{array}{c}\% \\
98.5 \text { ał } \\
96.5 \text { a } \\
92.2 \text { ab }\end{array}$ & $\begin{array}{l}2.98 \mathrm{a} \\
3.68 \mathrm{a} \\
2.74 \mathrm{bc}\end{array}$ & $\begin{array}{c}\% \\
78.0 \mathrm{a} \\
79.2 \mathrm{a} \\
67.7 \mathrm{a}\end{array}$ \\
\hline $\begin{array}{l}\mathrm{K} \\
\mathrm{K} \\
\mathrm{K}\end{array}$ & $\begin{array}{l}\mathrm{K} \\
\mathrm{K} \\
\mathrm{K}\end{array}$ & $\begin{array}{c}S \\
w\end{array}$ & $\begin{array}{l}S \\
W\end{array}$ & $\begin{array}{l}75.7 \mathrm{bcd} \\
82.5 \mathrm{bc} \\
80.5 \mathrm{bc}\end{array}$ & $\begin{array}{l}2.05 \mathrm{~cd} \\
1.84 \mathrm{~d} \\
1.84 \mathrm{~d}\end{array}$ & $\begin{array}{l}37.2 \mathrm{bc} \\
44.5 \mathrm{~b} \\
33.0 \mathrm{bc}\end{array}$ \\
\hline $\begin{array}{l}K \\
K \\
K\end{array}$ & $\stackrel{S}{W}$ & $\begin{array}{l}S \\
w\end{array}$ & $\begin{array}{l}S \\
W\end{array}$ & $\begin{array}{l}63.0 \mathrm{~cd} \\
58.2 \mathrm{~d} \\
68.7 \mathrm{~cd}\end{array}$ & $\begin{array}{l}1.43 \mathrm{~d} \\
1.33 \mathrm{~d} \\
1.57 \mathrm{~d}\end{array}$ & $\begin{array}{l}23.5 c \\
21.5 c \\
26.7 b c\end{array}$ \\
\hline $\begin{array}{l}W \\
W \\
W \\
W \\
\text { Nontr }\end{array}$ & $\begin{array}{l}\text { W } \\
\text { W } \\
\text { W } \\
\text { ted contro }\end{array}$ & $\begin{array}{l}w \\
w\end{array}$ & W & $\begin{array}{l}5.2 \mathrm{e} \\
2.7 \mathrm{e} \\
5.5 \mathrm{e} \\
0.5 \mathrm{e} \\
1.7 \mathrm{e}\end{array}$ & $\begin{array}{l}0.04 e \\
0.03 e \\
0.05 e \\
0.01 e \\
0.02 e\end{array}$ & $\begin{array}{l}0.2 \mathrm{~d} \\
4.5 \mathrm{~d} \\
0.0 \mathrm{~d} \\
0.2 \mathrm{~d} \\
0.0 \mathrm{~d}\end{array}$ \\
\hline \multicolumn{7}{|c|}{$\begin{array}{l}\text { "Bloom stages and fruit size of king bloom and fruit: Later }=\text { five additional applications, applied weekly. Av- } \\
\text { erage fruit diameter } 31.2 \mathrm{~mm} \text { on last date. } \mathrm{K}=\mathrm{Kocide} 101,1.0 \mathrm{lb} / 100 \mathrm{gal} ; \mathrm{S}=\text { streptomycin sulfate, } 100 \\
\mathrm{ppm} ; \mathrm{W}=\text { water. } \\
\text { tOne hundred mature fruit per replication selected arbitrarily on the day of evaluation and near commercial } \\
\text { harvest. Russet rating scale of } 0 \text { to } 5 \text {, with } 0=\text { no russetting and } 5=75 \text { to } 100 \% \text { of fruit surface russetted. } \\
\text { Cull fruit were those in russet rating categories } 3,4 \text { and } 5 \text {. } \\
\text { †Means down columns followed by the same letter do not differ significantly according to Duncan's multiple } \\
\text { range test, } P=0.05 \text {. }\end{array}$} \\
\hline
\end{tabular}




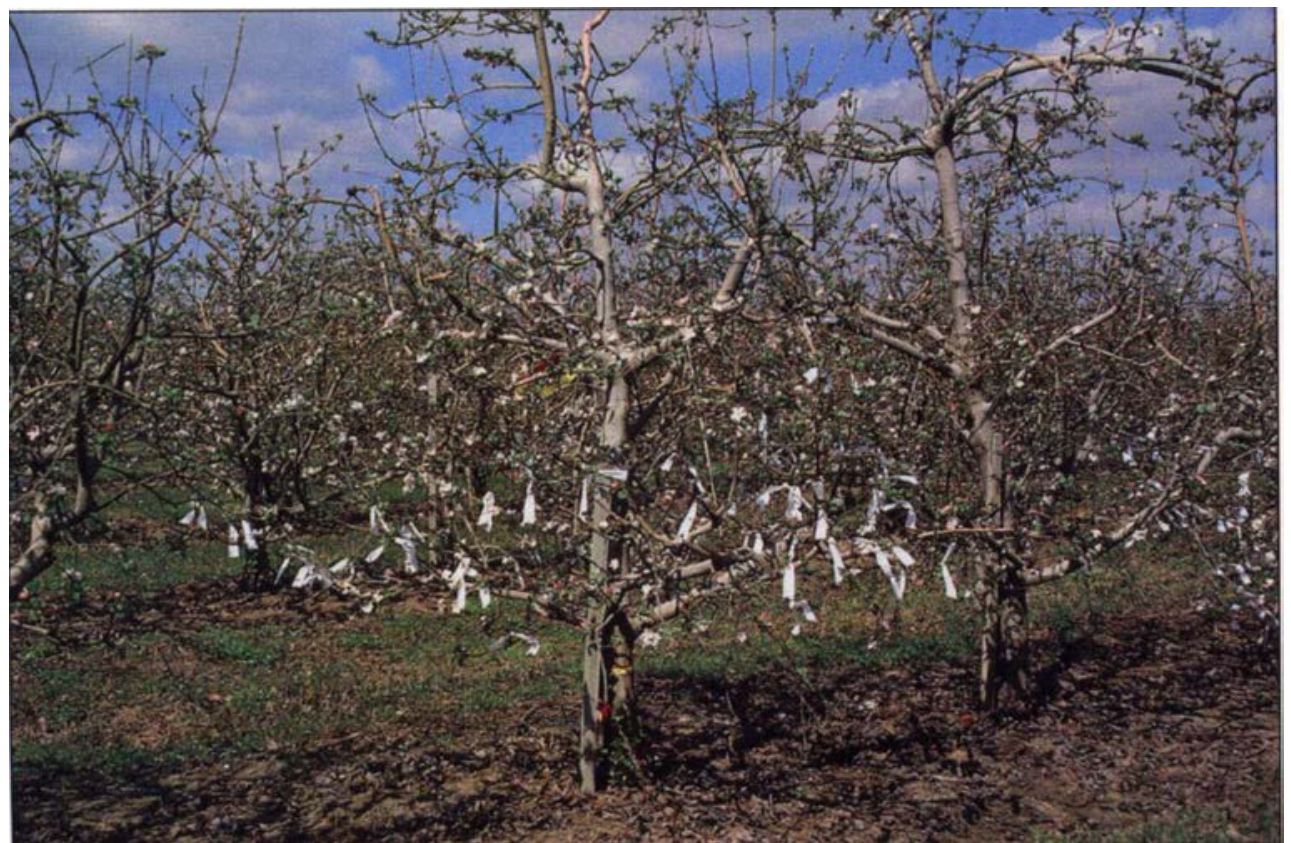

Average-sized king fruit were tagged prior to treatment. Later researchers rated the fruit from these Granny Smith apple trees according to the percentage of fruit surface russetted.

In both years, $80 \%$ to $97 \%$ of fruit was russetted. There were no significant differences between copper- and water-treated fruit from any treatment date, although there was a trend toward greater russet ratings among fruit treated with copper (data not presented). No cull fruit were present in 1990 , and $6 \%$ to $20 \%$ of fruit were culls in 1991, but treatments did not differ.

\section{Copper followed by streptomycin}

To reduce the potential for fruit damage, a fire-blight control program would probably include only one to three copper treatments in a streptomycin-sulfate program. Treatment would probably occur during bloom, when trees are in most jeopardy of infection.

In 1992 in the Kern County orchard described earlier, we tested one, two and three treatments of $1.0 \mathrm{lb}$ Kocide 101 per 100 gallons water applied during bloom and followed by weekly applications of $100 \mathrm{ppm}$ streptomycinsulfate, water, or no treatment during the same fruit growth stages already listed. Table 3 shows the timing schedules. There were four single-tree replications of each treatment arranged in a randomized complete block design. We collected and examined random samples of 100 fruit from each tree on Aug. 24, 1992, as described earlier.
Percent russetted fruit, russet rating and percent cull fruit increased with increasing numbers of Kocide 101 treatments during bloom (table 3 ). Treatment after Kocide 101 application did not affect the amount of fruit damage: values were similar when copper was followed by streptomycin-sulfate, water or no treatment.

\section{Conclusions}

Most fruit russetting is the consequence of injury to rapidly dividing epidermal cells early in fruit development. The severe damage sustained by fruit on 'Granny Smith' trees treated during bloom in 1992 fits this description. However, the percent of russetted fruit was relatively higher in some postbloom treatments in 1990 and 1991 compared to other treatment dates each year. This hints that fruit-growth stages other than bloom may also be subject to damage, even though scarring at these times in our experiments was insufficient to warrant loss.

We encountered differing responses to the same treatments in different years, demonstrating the unpredictable and sporadic nature of apple fruit russetting under California conditions. Furthermore, other tests on copper-induced fruit russetting, not reported here, were conducted in the Kern County orchard in 1988 and 1989. In neither year was fruit russetting observed. Thus, in Kern County, serious russetting developed in only 1 of 5 years. We were unable to identify any weather event or treatment condition that might account for this.

Copper is just one of several causes of russetting, and the conditions that trigger the russetting response are not well understood. 'Fuji' apple fruit frequently develop a natural russetting that apparently is initiated by undetermined environmental events. The russetting observed on the 'Fuji' apple fruit in our experiments seemed largely due to such natural russetting and was not exacerbated by the copper treatments. Whatever governs the development of russetting, by any cause, differs among years.

The Kern County orchard was chosen for this work because fire blight was severe there in 1987, and we intended to evaluate treatments for fireblight control. However, fire blight was not observed in the orchard during the course of these studies; thus we cannot comment on the efficacy of these treatments for disease control.

Growers who choose to use copper as part of a fire-blight control program cannot do so without risk. Programs that appear safe may, without explanation, prove damaging in other years. Those who elect to include copper should select lower rates and limit application to one postbloom treatment per year. Bear in mind that the value of such a practice for fire-blight control is not known and is not without hazard.

B.L. Teviotdale is Extension Plant Pathologist, Department of Plant Pathology, UC Davis, located at the Kearney Agricultural Center in Parlier; M. Viveros and J.A. Grant are UC Cooperative Extension Farm Advisors in Kern and San Joaquin counties, respectively.

The authors thank Green Valley Farms, Jim Carlisle, General Manager, and John Wood, Assistant Manager, for the use of their orchard in Kern County; Buck and Mark Lewis for use of their San Joaquin County orchard; and UC Staff Associates Dennis Harper, Nancy Goodell, John Fritz, Peggy Schrader and Valeshia Hines for technical assistance, and Carol Adams for statistical advice. 